\title{
Experiência e narrativa: entre contar e ler
}

\section{Bernardo Barros Oliveira, UFF}

Resumo: O tema da narrativa, oral ou escrita, tem ressurgido com insistência no pensamento contemporâneo, como ponto articulador de questões como o tempo, a memória, a experiência, o conhecimento de si e do mundo. Sua abordagem ultrapassa o interesse estrito nas narrativas enquanto obras de arte. Esta insistência do tema está inserida em uma vertente de pensamento, que tem suas raízes em fins do séc. XIX, que poderíamos caracterizar como aquela empenhada na reformulação e ampliação do conceito moderno de experiência. Dois autores que, vindos de tradições filosóficas diferentes, como Walter Benjamin e Paul Ricœur, não só compartilham este ponto de partida histórico como, também, a tarefa de ampliar filosoficamente a noção de experiência através da análise do que ocorre dentro da prática de contar/escrever e ouvir/ler histórias. Tentemos primeiro sublinhar alguns aspectos da incursão benjaminiana no tema, para depois abordar alguns traços da de Paul Ricœur, para, por fim, tentar ensaiar algumas conclusões.

Palavras-chave: experiência; narrativa; pensamento contemporâneo.

\section{Benjamin e a arte de narrar}

O ensaio de Walter Benjamin "O narrador, considerações sobre a obra de Nicolai Leskov", de 1936, é um dos mais lidos e citados ensaios sobre a narrativa. O texto não apresenta, no entanto, uma teoria geral sobre o que pode ser ligado ao nome de narrativa. Ele é, na verdade, uma espécie de mosaico de caminhos e sugestões esboçadas, que têm como tema recorrente a figura do contador de histórias, ou da prática da narrativa oral. Atendendo-nos a apenas alguns poucos aspectos desse texto, cabe destacar, em primeiro lugar, o esforço de Benjamin em descrever o estado da arte de narrar (e não do narrar como bela arte): o declínio da capacidade de contar histórias e o que isso implica, na medida em que a arte de contar serve à organização e transmissão de experiências. Nesse contexto, a prática de sedimentar e transmitir experiências com caráter de modelos de ação recebe o nome de tradição. $\mathrm{O}$ enfraquecimento desta técnica, no sentido amplo de um saber fazer, representa então o declínio da tradicionalidade como modo de vida. O russo do século XIX, Nicolai Leskov, para Benjamin, pode ser lido como representante de um tipo de autor da era do romance que exibe marcas, em seus textos escritos, do contador de histórias oral. Interessa-nos retomar alguns dos traços da figura deste contador de histórias, a relação da narrativa com o saber, a articulação da experiência com o ato de ouvir e recontar e a relação desta prática com outros discursos, como o romance e a informação.

Ter o que contar: esta é a primeira e mais importante condição do contador. Etimologicamente, em português, narrador vem de gnarus, aquele que conhece, que sabe. Os modelos são o viajante, que atravessou a distância espacial e o seu oposto, o não viajante, sedentário e estabelecido, que conhece as histórias do lugar. Os dois 
tipos são sintetizados na figura do aprendiz de oficina de artesão, que viajou antes de se estabelecer em uma cidade. Estas figuras são desenhadas em largos traços, e parecem remeter a um contexto medieval. Enquanto figuras, quase personagens, servem para dar concretude ao sentido mais arcaico da palavra Erfahrung, que composta pelo radical fahr-, está ligada à ideia de atravessamento de distância ${ }^{1}$. Quem de fato atravessa algo e é portanto também atravessado pelo movimento, ganha autoridade para contar. O que ele tem para dizer vem de longe e a distância é elemento fundamental da visibilidade de algum acontecimento significativo. Ter o que contar alimenta a cadeia da tradição. Contar-ouvir e passar adiante são traços da atividade narrativa. Ou seja, o foco do ensaio benjaminiano não é no ato criador de composição de uma obra literária, mas no laço social baseado na retenção e transmissão de saberes. O interesse básico em ouvir e memorizar uma história reside na convicção de que ali existe a oportunidade de um conhecimento. Benjamin oferece uma espécie de síntese de todo o processo quando compara o ato de narrar ao de aconselhar, na medida em que a história contada contém em germe a solução de alguma situação que exige ponderação e alguma dose de sabedoria prática. Mas, para se receber conselho, tem-se primeiro que contar uma história - donde a definição benjaminiana do conselho como a continuação de uma história que é apresentada como incompleta. ${ }^{2}$ A prática do conselho é, segundo Benjamin, o que há de mais anacrônico e estranho para nós modernos, porque justamente não sabemos narrar como chegamos ao ponto em que estamos em nossa vida, e também porque não esperamos de ninguém um excedente de sabedoria que o capacite a continuar a história que não sabemos contar. Isto não significa que Benjamin proponha que literalmente que toda vez que uma história é lembrada oralmente esteja desenhada a situação explícita de aconselhamento, mas sim que narrar, num contexto dominado pela tradicionalidade, é um processo transitivo e coletivo, que articula transmissão, continuidade e aprimoramento.

Sem dúvida, trata-se de algo muito distante da imagem que ainda possuímos hoje do ato de criação de uma narrativa por um escritor, normalmente representada como um assunto que envolve solidão e uma grande dose de inesperado e inaudito. A cena do contar e ouvir a possível continuação da história dá visibilidade a uma prática da qual as noções modernas de autoria individual e de leitura solitária se encontram muito distantes. O que ele chama, sem maiores explicações, de "o lado épico da verdade" ${ }^{3}$ pode talvez ser traduzido, em terminologia filosófica antiga, como um saber da phronesis (em latim, prudentia), embora não exclua um saber teorético sobre como as coisas são. Está mais ligado à prudência como saber-viver, à arte do tato, do juízo no sentido prático, no saber o que fazer, e no ato formativo, no aprendizado de como agir em um caso singular.

Junto com o aspecto interessado e pragmático tanto do contar quando do ouvir e memorizar histórias, Benjamin aponta o caráter aberto das narrativas. Embora elas comportem o que o próprio texto chama de uma "moral", esta não é evidente, e sua capacidade de intrigar é um elemento fundamental de seu poder de transmissão. Para exemplificar isso, Benjamin insere em seu texto uma história narrada por Heródoto e a acompanha de uma série de possíveis compreensões de seu sentido prático, uma delas encontrada em Montaigne. ${ }^{4}$ Consta que Benjamin fez um teste, contando oralmente esta mesma história a seu filho e à sua primeira mulher, quando de uma visita à Dinamarca, onde os dois viviam. Histórias como essa, diz Benjamin, conservam seu poder germinativo através dos séculos. Esta fertilidade se deve ao fato de que as histórias são radicalmente incompatíveis com explicações definitivas.

Cadernos Benjaminianos, Número especial, Belo Horizonte, 2013, página 41-54 
O oposto acontece com outra modalidade de comunicação, a informação: na informação, nada pode ser estranho e tudo tem de estar acompanhado de esclarecimentos que façam com que sua assimilação pelo público visado aconteça sem qualquer traço de estranhamento. A notícia de jornal não deixa de apresentar traços formais de narrativa, uma vez que é até certo ponto dependente do relato, mas contar uma notícia a alguém é inteiramente diverso de transmitir uma história. A informação auto-explicativa corta pela raiz o processo indefinido de releituras de uma história.

Outra forma discursiva que possui traços de família com a história tradicional é o romance. Benjamin entende por romance o tipo de narrativa composta para o livro, ou seja, vincula claramente romance e escrita. Há uma tendência no ensaio de opor contador de histórias e escritor. Aqui estamos em um terreno pouco claro, pois o próprio Leskov, pretexto para o ensaio, era um escritor, assim como uma extensa lista de autores que são apresentados por Benjamin como de algum modo semelhantes a Leskov quanto a seu parentesco com o contador, lista que inclui Rudyard Kipling e Edgar Allan Poe. ${ }^{5}$ De qualquer modo, é inequívoco que o romance moderno é marcado no ensaio como primeiro sintoma do declínio do "lado épico da verdade". Isso se deveria à origem do romance, a vivência do indivíduo isolado e desaconselhado, ratlos, e seu ensinamento consiste justamente nesta desorientação, Ratlosigkeit, característica do homem moderno, por sua destinação para a fruição individual, na leitura silenciosa, realizada por esse mesmo tipo de homem. O romance ao mesmo tempo seria fruto e intensificador da vivência moderna. Vivência, em alemão Erlebnis, é um termo importante da filosofia da virada do século XIX para o XX, e Benjamin se apropria dele para significar um tipo de auto-percepção temporal diverso daquele da experiência. Acreditamos ser este um modo de compreender o sentido das palavras experiência e vivência: modos de compreensão de nossa relação com nós mesmos e com os outros de um ponto de vista temporal: somos continuação e reforço dos que nos precederam e modelo para os que virão (experiência), ou começamos em nós mesmos e tudo o que nos cerca é novidade (vivência)? Nas sociedades tradicionais, os acontecimentos da vida do indivíduo se interpenetram com os da vida coletiva: o que outros viveram é recebido como herança e modelo, e a experiência do indivíduo se nutre, deste modo, através da dos outros, e vice-versa. O meio principal para esta transmissão, como vimos, é a capacidade narrativa, personificada no contador de histórias, mas na verdade uma marca disseminada do homem tradicional, cuja vida é enformada por histórias e provérbios. O homem moderno, segundo Benjamin, perde progressivamente esta inteligência narrativa, porque as suas condições de vida o levam de múltiplas formas ao isolamento e é, por isso, cada vez mais pobre em experiências passíveis de transmissão: “As inquietações da nossa vida interior”, diz Benjamin em seu segundo grande ensaio sobre Baudelaire, "não têm, por natureza, este caráter irremediavelmente privado. Elas só o adquirem depois que se reduziram as chances dos fatos exteriores se integrarem à nossa experiência". 6

$\mathrm{O}$ romance, narrativa predominante nesta era de retração da tradicionalidade, debruça-se sobre a vida da personagem, conferindo a ela as características de um indivíduo, e os acontecimentos ganham cada vez mais o caráter de realidade interior e privada. Esta é franqueada ao leitor solitário graças ao ponto de vista privilegiado da voz narrativa do texto escrito que ele tem em mãos. O leitor moderno se espelha no herói romanesco, em quem vê a busca do que Benjamin chama de "sentido da vida". Não fica claro, pelas indicações do ensaio, qual o sentido que Benjamin 
pretendia dar a essa expressão. O que é sublinhado é a relação entre este "sentido da vida" e a noção de término. O herói do romance é predeterminado pelo fim de sua história, ou, em outras palavras, bastante frisado também pelo texto de Benjamin, pela morte do herói. Há uma morte determinada conferindo a cada etapa narrada de uma vida um lugar preciso que conduz àquele fim específico. Neste ponto, Benjamin, para falar do romance, parece se aproximar do caráter estruturante do enredo (mythos), em sentido aristotélico, que será retomado por Ricœur. Este tópico será desenvolvido adiante, podendo-se adiantar que, quando se trata do romance, constitui-se um sentido forte de enredo apoiado na noção de fim. Retomemos a frase de Moritz Heimann citada no ensaio de Benjamin: "um homem que morre com trinta e cinco anos é em cada momento de sua vida um homem que morre aos trinta e cinco anos". ${ }^{7}$ Benjamin a considera totalmente falsa no que diz respeito à vida, mas totalmente verdadeira quando se trata do desenvolvimento de um personagem de romance. Neste último caso, a frase é verdadeira porque expressa a situação dos momentos ou episódios da vida consideradas como partes estruturadas por um fim já determinado, por chamar a atenção para o fator estruturante do fim e sua forte presença no romance. Isso não se dá da mesma forma na narrativa oral: "Com efeito, numa narrativa a pergunta - e o que aconteceu depois? - é plenamente justificada. $\mathrm{O}$ romance, ao contrário, não pode dar um passo além daquele limite em que, escrevendo na parte inferior da página a palavra fim, convida o leitor a refletir sobre o sentido da vida". ${ }^{8}$ Nesta, a noção de fim estaria presente de outro modo que não na impossibilidade de se dar um passo além. Mesmo que possamos considerar isso questionável, uma vez que se pode afirmar que romances e contos dialogam uns com os com outros e os continuam, devemos assinalar que o ensaio de Benjamin estabelece aí uma diferença forte entre a narrativa oral e a escrita (lida).

Benjamin trata também, nas seções 5, 14 e, especialmente, 15 do ensaio, dedicadas ao romance, das expectativas de leitura que o homem moderno espera ver atendidas por essa forma discursiva. O sentido cognitivo e reflexivo da leitura solitária é sublinhado por Benjamin, embora de modo um tanto reticente. O "dualismo da interioridade e exterioridade", que o personagem de romance supera "quando percebe a unidade de toda a sua vida", 9 serve de inspiração para o seu leitor, que, entende-se, busca unidade em sua própria história de vida, e, através desta, encontra também, na disparidade de fatos sem conexão de sua existência, uma unidade consigo e com a exterioridade, entende-se com os outros e suas histórias. Ao ser convidado a "refletir sobre o sentido de uma vida", ele "aquece sua vida gelada", ao se "apoderar" da "matéria" de sua leitura. Esse apoderamento, no entanto, não se desdobra na continuidade coletiva e anônima do conto oral. Isso se vincula a outro aspecto marcante do interesse do leitor moderno pelo romance, que é a morte. $\mathrm{O}$ fim da narrativa romanesca se funde à morte do personagem, figurada ou "de preferência a morte verdadeira". ${ }^{10}$ Mas a morte, nas sociedades pós-tradicionais, seria ocultada no anonimato ascético dos hospitais. A transformação observada no "rosto da morte" é interligada àquela operada na arte de narrar. Ao evitar a sua visibilidade (o "espetáculo da morte"), as instituições que administram a morte a "expulsam do universo dos vivos", e ela deixa de ser um acontecimento público. "Ora", diz Benjamin, "é no momento da morte que o saber e a sabedoria do homem e sobretudo sua existência vivida - e é dessa substância que são feitas as histórias assumem pela primeira vez uma forma transmissível". ${ }^{11}$ A morte que dá força à narrativa tradicional, e que por ela se espalha, é de outra ordem que a representada pelo "fim" no romance, e portanto, a experiência de participar do processo coletivo

Cadernos Benjaminianos, Número especial, Belo Horizonte, 2013, página 41-54 
de transmissão oral de histórias e a vivência da leitura individual são modos bem diversos de participação e compreensão do que poderíamos chamar de "finitude". É desta, no entanto, mesmo que de modos diferentes, que emana a força tanto da narrativa oral quanto do romance.

A avaliação, por parte de Benjamin, de que na passagem da situação discursiva oral e da interação imediata para aquela da leitura silenciosa de textos se perde mais do que se ganha, se fundamenta, podemos dizer, em uma tomada de posição a respeito das condições de existência no mundo pós-revolução industrial. O notório vínculo social na transmissão de conteúdo prático, apontado por Benjamin na narrativa tradicional e ausente na escrita e leitura de romances, só seria retomado em modalidades revolucionárias de narrativa, como vislumbrado no cinema, em que a interação e a conexão coletivas se articulam potencialmente com práticas políticas radicalmente transformadoras. Tendo em vista o foco deste artigo, cumpre sublinhar, para a continuidade de nossa discussão, que o foco da crítica benjaminiana ao romance não está baseada em alguma propriedade formal deste gênero literário, nem na leitura em si, mas na solidão do leitor. Que a leitura seja um ato de apropriação visando auto-compreensão, é claro para ele: "Nessa solidão, o leitor do romance se apodera ciosamente da matéria de sua leitura. Quer transformála em coisa sua, devorá-la [...]". ${ }^{12}$ A avaliação que Benjamin faz deste movimento apropriativo, no entanto, nos parece principalmente negativa: "O que seduz o leitor do romance é a esperança de aquecer sua vida gelada com a morte descrita no livro" ${ }^{13}$ Como a morte descrita no livro não é entretecida com o lado épico da verdade, com a prudência duramente aprendida por gerações e gerações, trata-se de um material puramente formal, meramente discursivo, quase lógico. Nos termos do ensaio, no caso do romance, "o interesse ardente do leitor se nutre de um material seco". ${ }^{14}$

É possível, tomando como ponto de partida uma visada mais ampla da obra de Benjamin, defender que seu ensaio tenta caracterizar um tipo de leitura, sem esquecer que outra, identificada com a figura do crítico, é igualmente passível de existir. Ao contrário do que poderia fazer crer uma leitura exclusiva do ensaio sobre o contador de histórias, são muitas as oportunidades, na extensa obra de Walter Benjamin, frequentemente construída em diálogo com obras romanescas, em que encontramos a leitura de narrativas escritas como forma de conhecimento do mundo e de si próprio. Podemos dizer que o nome, no vocabulário benjaminiano, desta leitura apropriativa que não é, no entanto, estéril, nem o mero aquecimento de uma vida gelada, é a leitura crítica. O crítico, cuja figura o próprio Benjamin procurou preencher em sua atividade de escritor, é um leitor, mas não um solitário enredado apenas em suas vivências incomunicáveis. Ele é sim um leitor que toma parte em um processo trans-histórico (e produtor de história), que consiste na recepção e continuação de uma obra literária. Este processo mereceu uma longa elaboração teórica na tese de doutoramento de Benjamin, conhecida como $O$ conceito de crítica de arte no romantismo alemão, através da retomada dos escritos de Schlegel e de Novalis, construindo ali uma noção forte de crítico, que, em nosso entender, teria sido mantida através de momentos posteriores de sua obra, despojada, porém, da linguagem do idealismo alemão. ${ }^{15} \mathrm{~A}$ formulação de Novalis, citada por Benjamin, sintetiza o núcleo da tese: "O verdadeiro leitor deve ser o autor ampliado", ${ }^{16}$ que para Benjamin serve como ponto de partida para a construção de um sentido de leitura, que, no entanto, não mais recebe esse nome no decorrer da tese: "Está claro: para os românticos, a crítica é muito menos o julgamento de uma obra do que o

Cadernos Benjaminianos, Número especial, Belo Horizonte, 2013, página 41-54 
método de seu acabamento". ${ }^{17}$ Ampliação e acabamento da obra, sua inserção em um elemento trans-histórico, o "medium-de-reflexão", chama atenção para o processo potencialmente infinito de releituras de uma mesma obra, um movimento supraindividual, o que constitui o verdadeiro foco da filosofia da arte proposta na tese de 1919. ${ }^{18}$

Podemos, então, vislumbrar uma teoria de dois níveis da atividade da leitura, e a descrição desta que predomina no ensaio sobre o narrador diria respeito apenas ao primeiro nível. Talvez encontremos um emblema para este nível na descrição que Benjamin faz da leitura destinada a entreter as viagens de trem, no aforismo de "Imagens do pensamento", intitulado "Romances policiais, nas viagens": "A anestesia de um medo por meio de outro é a sua salvação. Entre as folhas recémseparadas dos romances policiais, ele procura as angústias ociosas, de certo modo virginais, que poderiam ajudá-lo a superar as angústias arcaicas da viagem". ${ }^{19}$ Podemos dizer que a obra de Walter Benjamin mostra a necessidade de um leitor que não faça da leitura apenas uma maneira de embalar sua vivência solitária, mas que articule positivamente o mundo narrado e o mundo da vida. $\mathrm{O}$ homem narrativo tradicional lhe fornece um modelo. Seu conceito de crítico literário, que ele mesmo procurou colocar em prática, outro. Sua ênfase, de nosso ponto de vista, é na oposição entre uma leitura passiva e interiorizada, caracterizada pela era do romance burguês, e uma leitura potenciadora, desdobradora, necessária.

\section{II - Ricour e a arte de ler}

Pelo ângulo do que acabamos de comentar, o tema da narrativa na obra de Paul Ricœur pode ser visto como uma recolocação do tema do valor prático e cognitivo da narrativa, mas passando primeiro pela recolocação de uma noção geral de leitura. O que é um texto e o que é ler um texto? Na tradição hermenêutica, o problema do texto é como que um ponto de partida para abordar a linguagem como um todo. $\mathrm{O}$ texto narrativo, seja de ficção ou historiográfico, por sua vez, funciona como um centro de gravidade para o múltiplo problema da linguagem.

Tomemos como ponto de partida as investigações de Ricœur da década de 70, dominada, na área das ciências humanas, pelo estruturalismo, e em linguística, pela abordagem sistemática e acrônica da língua. Neste contexto, Ricœur se interessa pela corrente alternativa dos estudos da linguagem, a que aposta na possibilidade de teorizar o discurso, a situação viva de fala. Apoiado em Benveniste, e também na filosofia da linguagem ordinária (Austin e Searle), interessada em construir uma teoria dos atos de fala, Ricœur busca, por sua vez, precisar o momento em que a textualidade surge em meio à própria fala. Nas situações de fala pode surgir, e de fato surge, a necessidade de repetir o que foi dito. O dito se separa do dizer com muita frequência, e não se trata da introdução de um acréscimo artificial e posterior: o que foi dito pode ser repetido, pode ser redito com outras palavras, pode ser parafraseado ou até mesmo traduzido "simultaneamente" em outra língua. Redizer o dizer é uma forma de reatualizar o assunto de que se falava, ou, na linguagem da fenomenologia, a "coisa mesma" de que se falava, sem que se repita a situação da primeira fala, nem que se usem as mesmas palavras, nem sequer que estejam presentes os mesmos falantes. O dizer passa: Ricœur o chama "evento". Mas o dito o transcende. Recebe o nome de "significação" este aspecto do dizer que sempre se separa dele. ${ }^{20}$

Cadernos Benjaminianos, Número especial, Belo Horizonte, 2013, página 41-54 
Quando nos esforçamos por fixar o dito, separando-o do dizer, estamos entrando na região do texto, embora não necessariamente na da escrita. O mensageiro que leva uma mensagem a um lugar distante pode não dispor de escrita, mas é portador de um texto. $\mathrm{O}$ rapsodo que memoriza poemas narrativos e os declama, pode não usar a escrita, mas as ações a que os poemas se referem não estão à disposição para serem apontados, como numa situação de fala. Mesmo que se realize oralmente, a prática do rapsodo é textual. A posição de Ricœur é de que a escrita vem dar um grande impulso à prática textual, mas não é ela que a cria. Deste ponto de vista, a prática do contador de histórias benjaminiano já é textual. Quando se dispõe da escrita, a capacidade que a linguagem possui de transcender as limitações espaçotemporais é potenciada. O receptor de um texto, principalmente quando escrito, lembra Ricœur, é qualquer pessoa, em qualquer época ou lugar, capaz de ler aquela língua. A decisiva consequência disso se faz ver no decisivo quesito da referencialidade. Na situação de fala, o referente pode ser sempre esclarecido mediante algum novo desdobramento do discurso; podemos pedir explicações ao falante, e este pode, no limite, apontar para aquilo de que se fala, pois se trata de uma coisa ou fato que pertence ao mundo circundante imediato do falante e do ouvinte, embora normalmente isso nem se faça necessário, uma vez que a situação comum entre falante e ouvinte já provê este esclarecimento. O aqui e agora da situação de fala é o centro do mundo comum a falante e ouvinte, e é o ponto em relação ao qual o assunto da conversa pode ser situado sem maiores problemas. A referencialidade "ostensiva" está, neste caso, sempre à mão. Já um texto, quando interrogado sobre o que ele quis dizer, ou seja, afinal, quando perguntamos a que ele se refere, que realidade ele revela para além de si mesmo, não pode dar maiores explicações nem reformular a si mesmo, pode apenas repetir as mesmas frases. Mas a consequência extraída deste fato, para Ricœur, é amplamente positiva.

"A primeira extensão do alcance da referência para além dos limites estreitos da situação dialógica é de uma consequência tremenda", diz Ricœur. E completa: "Graças à escrita, o homem e só o homem tem um mundo e não apenas uma situação". ${ }^{21}$ O "conjunto de referências abertas pelo texto": eis a definição de "mundo" na Teoria da interpretação. Trata-se de uma modificação importante, introduzida por Ricœur, na noção herdada principalmente de Heidegger, de ser-nomundo (in-der-Welt-sein), a qual, no nosso entender, não opõe situação a mundo, muito embora este se realize, na linguagem de Ser e tempo, num processo contínuo de compreensão e interpretação. Não temos, no entanto, intenção de tentar desenvolver o tema desta filiação e desta diferença aqui. ${ }^{22}$ A diferença fundamental da leitura com relação a qualquer situação de fala é algo enfatizado por Ricœur, e talvez um dos principais distintivos de sua versão da hermenêutica. Ele o chama de "distanciamento", e dele extrai uma série de consequências positivadoras do ato de leitura. Graças a essa mobilidade ilimitada e vinculação exclusiva à "coisa" tratada pelo texto, pode então a leitura revelar um traço insuspeitado, a saber, a de ser uma autêntica habitação de mundo. Justamente porque (e não apesar) de ser uma situação tão radicalmente distinta da fala, na recepção de um texto o leitor tem de recriar mentalmente o mundo a partir das indicações nele contidas, religando um conjunto de referências conformadoras de um todo, que, imaginariamente, passa a se tornar, também, um lugar a ser percorrido pelo leitor, e que, como assinalamos a propósito do termo usado por Benjamin, Erfahrung, é um simultâneo a ser percorrido, transformado.

Cadernos Benjaminianos, Número especial, Belo Horizonte, 2013, página 41-54 
Essa característica do texto por oposição à fala, a distância radical com relação a qualquer situação na qual reina uma referencialidade de tipo situacional e ostensivo, é particularmente acentuada nas narrativas ficcionais. A palavra "ficção" vem de fictus, ligado ao sentido de fingimento, de fingir (fingere, por sua vez, significou "modelar na argila"). A narrativa de ficção finge ser o relato de algo, como se este tivesse ocorrido, na verdade, modelando este mundo diante de nossos olhos. Tal mundo possui existência própria, então, a princípio, não se refere a coisa alguma de real. Isso é o que Ricœur chama de referência de "segundo grau". ${ }^{23}$ Esta só é acessível porque as de "primeiro grau" foram quebradas: quebradas uma vez pela textualidade, que rompe a referência imediata, e em segundo e decisivo lugar pela ficcionalidade, que impede que liguemos o que é dito a alguma coisa pertencente ao nosso próprio mundo circundante, ou melhor dizendo, à nossa situação. Um texto narrativo, para Ricœur, tem sua referência aberta não na remissão a um acontecimento passado, seja a vivência pessoal do escritor, seja a sociedade na qual foi gerado. As marcas verbais comuns nesse tipo de texto, por exemplo os verbos no imperfeito, instauram o regime de um relato de acontecimentos abertamente fingidos, "como se" fosse a narração de fatos ocorridos. Mas ainda assim eles mantêm a promessa de referencialidade (e de verdade) de toda linguagem, cuja vocação - essa é a aposta explícita da hermenêutica contemporânea, tanto de Ricœur como de Gadamer - é apontar insistentemente para além de si mesma. Porém o apontado, contrariando a orientação do tempo verbal, não é algo que ocorreu antes do texto, mas sim algo que se mostra "diante do texto": o "mundo do texto". Esse duplo distanciamento, textual e fictício, permite que possamos nos apropriar dele na experiência da leitura. ${ }^{24}$

Poderíamos incluir também no rol dos distanciamentos produzidos pelo texto ficcional a sua própria estruturação temporal e a experiência temporal da efetivação da leitura. Ricœur retoma Aristóteles e a poética, e dele extrai o conceito de enredo, mythos, que seria a célula básica de toda narrativa. Mito é o agenciamento de diversas ações, agentes, pacientes, efeitos desejados e indesejados em uma unidade de sentido. Enquanto leitores ou ouvintes, recompomos a unidade do enredo, compreendendo, de nossa parte, o encadeamento necessário entre as ações e os seus efeitos desejados e indesejados. Um acontecimento deixa de ser uma mera ocorrência e passa a ser um episódio de uma trama e fazer sentido apenas dentro dela.

Cabe relembrar a frase citada por Benjamin que transcrevemos mais acima - que, segundo ele, só tem sentido na perspectiva da "reminiscência", "musa do romance"-, posto que ela ajuda a compreender a relação do acontecimento enquanto parte ou episódio de um todo e este mesmo todo. Cada "momento" da vida de um homem que morre aos trinta e cinco anos recebe sua significação na medida em que constitui o mundo deste homem. A noção de enredo é apresentada, por Ricœur, como um conceito limite para caracterizar certo tipo de texto, cuja leitura faz com que habitemos um determinado mundo temporal. A característica marcante deste mundo temporal é de que integra sucessão, por um lado, e culminação e unidade, por outro. A noção de enredo significa precisamente esta integração de duas experiências temporais conflitantes: a da possibilidade em aberto (vida) e a do acabamento (morte). Acompanhar a história do homem que morre aos trinta e cinco anos implica acompanhar sua trajetória, os episódios significativos que esclarecerão, na expressão usada por Benjamin, o sentido de sua vida, ou seja, saber quem ele é, habitando imaginariamente seu mundo, sua possibilidade de vida, tal como alguém que vive de 
fato, sem saber o que acontecerá. Ou seja, habitar o mundo de um texto é, por um lado, se colocar na possibilidade em aberto de uma vida inconclusa, tecida de expectativas e lembranças, e por outro, ao mesmo tempo, viver cada acontecimento como sendo o de uma vida que acaba, por exemplo, aos trinta e cinco anos. No entanto, tal como na vida, fazemos conjecturas sobre o porvir, projeções que nos guiam e que modificamos à medida em que novos fatos vêm nos esclarecer. Quando lemos uma narrativa, esse aspecto é especialmente reforçado, pois fazemos de antemão a pressuposição de completude ou perfeição, que, no caso de um texto narrativo identifica-se com o fim da história. Mergulhar no mundo dos personagens, como em uma vida, confiantes, ao mesmo tempo, de encontrar algo que não ocorre na nossa vida, um fim já determinado, um fim que já é passado: eis a experiência temporal da leitura. Esse fim irá coroar a busca pelo sentido da história, ou seja, o fim é o convite para que o leitor configure uma compreensão.

Uma das teses centrais de Ricœur é a de que o caráter coeso e inteligível do enredo não é efetivado pela forma do texto, mas na leitura: "O que um leitor recebe é não somente o sentido da obra mas, por meio de seu sentido, sua referência, ou seja, a experiência que ela faz chegar à linguagem e, em última análise, o mundo e sua temporalidade, que ela exibe diante de si". ${ }^{25}$ Seguir uma história é realizar a etapa final de sua composição, confirmar a vocação referencial do texto, refazendo seu mundo de ação, que sempre é único e inédito, pois fruto da interseção entre o mundo do leitor e o que a obra convida a atualizar. O processo que Ricœur chama de "apropriação", refere-se ao processo de atualização do sentido, da orientação de um percurso de leitura através do mundo do texto, que só passa da virtualidade para a efetividade no ato sempre individual da leitura. Tornar próprio, portanto, significa a um só tempo desestrangeirizar o texto, trazendo-o para o campo da vida de quem lê, e efetivar seu sentido e referência num aqui e agora. Não se trata, porém, de um enclausuramento do sentido na estéril interioridade do sujeito. Podemos considerar diversas passagens da obra de Ricœur como um detalhamento da noção de fusão de horizontes gadameriana: apropriar-se do texto não significa capturá-lo em um suposto interior carente de mundo, mas realizar a orientação de sentido do texto de modo sempre renovado. Não há leitura igual a outra, mesmo se tratando do mesmo texto, mas a leitura é, ao mesmo tempo um "ato do texto". ${ }^{26}$ Não há, por isso, para Ricœur, sentido em falar de uma separação radical entre a leitura solitária e subjetiva e qualquer forma de objetivação desta mesma leitura. Poderíamos dizer que a crítica, no sentido benjaminiano do termo, para Ricœur, não seria uma forma antagônica de leitura, com relação à leitura de romances policiais em viagens de trem, por exemplo, mas antes um segundo nível que tem seu enraizamento na leitura de primeiro nível. Esse tema vem à tona nas reiteradas discussões a respeito do tema diltheyano da diferença entre explicar e compreender, que, segundo a perspectiva defendida por Ricœur, não são duas instâncias mutuamente excludentes, mas antes duas camadas interdependentes que se alternam em uma dialética requerida pela própria linguagem. O crítico e leitor de romances policias vendidos em estações de trem, por exemplo, não estão proibidos de serem momentos diversos de um mesmo, desde que a primeira leitura seja retomada em uma segunda, na qual os procedimentos em ação na primeira sejam sublinhados e analisados. Esta segunda leitura, no entanto, não se separa da primeira, mas a ela retorna. A segunda leitura já não é tão presa do suspense e da sensação de seguir um movimento de vida, no qual a pergunta "e depois?" tem primazia, mas estes primeiros movimentos são imprescindíveis para a habitação do mundo do texto. A segunda será mais atenta aos

Cadernos Benjaminianos, Número especial, Belo Horizonte, 2013, página 41-54 
indícios que preparam a trama, que consegue perceber a retórica do texto e explicar o que está em jogo no enredamento aí proposto. Explicar, porém, é compreender mais, Ricœur não cansa de repeti-lo. Mesmo que a segunda leitura conduza ao isolamento de estruturas e, aparentemente, se retire da habitação "ingênua" do mundo do texto, só tem sentido porque incitada pela primeira, e só valerá a pena se reforçar o retorno a este mundo. ${ }^{27}$

Ressaltemos ainda um último aspecto do universo narrativo segundo Ricœur, que o aproxima supreendentemente da tematização benjaminiana da tradicionalidade. A estrutura do enredo não repousa em um paradigma atemporal, tal como uma suposta categoria pura do pensamento. É antes um modelo histórico, um paradigma que antecede o narrador na medida em que este o incorpora a partir da histórias que ouve/lê, os enredos que fazem parte da sua cultura. Qualquer enredo é produzido a partir de modelos de caráter mais ou menos geral, sendo porém, ao mesmo tempo, uma história singular. Dessa dialética entre modelos herdados e singularização produz-se uma outra, aquela entre a sedimentação de modelos e a inovação/ transformação destes em cada narrativa singular. Tal dinâmica está implicitamente presente na tematização benjaminiana do contador de histórias, mas é explícita na teorização de Ricœur: quando praticamos a arte de seguir uma história, seja ouvindo ou lendo, não herdamos apenas conteúdos a serem interpretados, mas modos de ordenar e compor novas intrigas, que trazem consigo esquematizações da ação e seu tempo. O nome dado por Ricœur a essa dialética é o de "tradicionalidade". ${ }^{28}$ Este tema contém um traço estruturante da hermenêutica contemporânea: reconhecer a tradição na qual nos criamos evita que caiamos na ingenuidade de julgar possível um acesso puro e objetivante aos textos do passado, ao modo do historicismo do século XIX, ou que nos enclausuremos na proposta do estruturalismo ou da semiótica, que busca no texto uma recombinação de elementos invariantes, separando-o de qualquer relação com elementos extra-textuais. Esta posição, que Ricœur compartilha com o posicionamento de Hans-Georg Gadamer em Verdade e método, é representada na linguagem deste último na expressão Wirkungsgeschichte, ou "história efeitual", que vem a ser a consciência de que uma história nos precede, na qual somos moldados e da qual somos a sequência viva, não previamente controlada por uma decisão do sujeito autônomo. E enquanto tais, também, somos não pura repetição servil, mas intérpretes e continuadores. A história efeitual, portanto, em sua versão ricoeuriana e narrativista, é composta de dois pólos complementares, o da "sedimentação" dos modelos transmitidos, muito forte por exemplo nos contos tradicionais populares e nos mitos, e o da inovação, muito característico da experimentação literária moderna iniciada com o romance burguês e desembocando no romance do auge do modernismo, no séc. XX, na narrativa de um Musil, por exemplo. ${ }^{29}$

\section{Conclusão}

O projeto acalentado pelo jovem Benjamin, de uma filosofia futura que fizesse justiça à inteireza da noção de experiência, tirando-a dos limites que a primeira crítica kantiana havia criado, com a exclusividade aí concedida às ciências da natureza, teve necessariamente de passar por uma reavaliação da experiência do tempo humano das ações, presente de modo eloquente nas narrativas. Esse enfoque narrativo não encontrou tanto eco na fenomenologia husserliana nem na hermenêutica fenomenológica de Heidegger, e nem ainda na hermenêutica em sua versão gadameriana. Paul Ricœur é, portanto, o herdeiro desta questão. Sua raiz, 
neste ponto, pode ser localizada mais na filosofia de Dilthey do que na de Walter Benjamin. As alusões à obra de Benjamin nos textos de Ricœur são rápidas. O que nos importa, porém, é que encontramos, em versões diferentes, nestes dois autores, o reconhecimento explícito do "lado épico da verdade". Todos os aspectos cognitivos e práticos atribuídos por Benjamin à narrativa oral tradicional são reencontrados por Ricœur na leitura narrativa, ou mais amplamente, numa certa "inteligência narrativa", a qual enraíza a própria noção de "crítica" benjaminiana. A noção de enredo ou intriga (o mythos da Poética), implícita na caracterização benjaminiana do romance, explicitada e religada por Ricœur às formas pré-narrativas do saber prático e sua semântica da ação, constituem uma base sólida para mostrar que a inteligência narrativa, seja aquela em jogo no ciclo da história oral, seja a que acontece na dinâmica de seguir a configuração de uma ação completa na leitura, está firmemente conectada com a construção de uma legítima experiência. A possibilidade da crítica, por sua vez, nasce da própria habitação do mundo do texto pelo leitor/ouvinte.

A frequentação do espaço narrativo, se ainda ocupa na vida de hoje, em suas múltiplas formas, um papel considerável, deve-se a que este guarda alguma relação forte com a experiência, em sentido amplo, do leitor. Benjamin, enquanto crítico literário, busca, entre outras coisas, continuar obras romanescas que exploram o modo desta experiência moderna e contemporânea, como Proust, Kafka e Poe. Nesse sentido, podemos afirmar que a leitura solitária pode ser uma experiência, em sentido abrangente e forte do termo, mesmo para a perspectiva de Walter Benjamin. A aposta, tanto de Benjamin quanto de Ricœur, é em um sentido forte dessa experiência de coabitação em um mundo estranho, diverso do nosso, o mundo narrado. E dele "retornar" como tendo atravessado algo, realizando sua referência. Isso pode ser relativamente raro, dado que a maioria das narrativas "consumidas" se propõem apenas a deixar seus leitores mais presos ao mundo em que já estão, mas, talvez por isso mesmo, cabe ser lembrado e ressaltado pela filosofia de que pode ser mais que isso.

\begin{abstract}
The theme of the narrative, oral or written, has emerged persistently in contemporary thought as an articulation of issues as time, memory, experience, knowledge of self and the world. Its approach goes beyond the strict interest in narratives as works of art. This theme is inserted into a line of thought, which has its roots at the end of the XIX Century, which we might characterize as that engaged in reshaping and expanding of the modern concept of experience. Two authors who come from different philosophical traditions, as Walter Benjamin and Paul Ricœur, not only share this historical starting point but also the task of expanding philosophically the notion of experience through the analysis of what occurs within the practice of story-telling / writing and listening / reading stories. We will first try to highlight some aspects of Benjamin's foray into the topic, and then address some of the traits of Paul Ricœur's thinking, in order finally to attempt to rehearse some conclusions .
\end{abstract}

Keywords: experience; narrative; contemporary thought. 


\section{Referências bibliográficas}

BARROS C. de Oliveira, B. A construção do crítico: Benjamin e os românticos. In: Artefilosofia. Ouro Preto, Instituto de Filosofia, Artes e Cultura/UFOP, v. 6, abril/2009. BENJAMIN, Walter. O narrador: considerações sobre a obra de Nikolai Leskov. In: BENJAMIN, Walter. Magia e técnica, arte e política: ensaios sobre literatura e história da cultura. Trad. Sérgio Paulo Rouanet, São Paulo: Brasiliense, 1994, p. 197-222 (Obras escolhidas; v. 1)

BENJAMIN, Walter. O conceito de crítica de arte no romantismo alemão. Trad. de Márcio Seligmann-Silva. São Paulo: Edusp, Iluminuras, 1993.

BENJAMIN, Walter. Experiência e pobreza. In: BENJAMIN, Walter. Magia e técnica, arte e política. Trad. Paulo Sérgio Rouanet. São Paulo, Brasiliense, 1987. p.114-119.

BENJAMIN, Walter. Sobre alguns temas em Baudelaire. In: Charles Baudelaire: um lírico no auge do capitalismo. $3^{\mathrm{a}}$ ed. Trad. José Carlos Martins Barbosa. São Paulo: Brasiliense, 1994, p. 103-150.

BENJAMIN, Walter. Imagens do pensamento. In: Rua de mão única. $5^{\mathrm{a}}$ ed. Trad. Rubens Rodrigues Torres Filho. São Paulo, Brasiliense, 1997, p. 220-221. (Obras escolhidas; v. 2)

BENJAMIN, Walter. Gesammelte Schriften, Rolf Tiedemann e Hermann Schweppenhäuser (orgs.). Frankfurt: Suhrkamp, 1996, v. 2.

ECO, Umberto. Seis passeios pelos bosques da ficção. Trad. Hildegard Fiest. São Paulo: Companhia das Letras, 1994.

GAGNEBIN, Jeanne Marie. História e narração em Walter Benjamin. São Paulo: Perspectiva, Campinas: Editora da Universidade Estadual de Campinas, 1994.

RICEEUR, Paul. La fonction herméneutique de la distanciation. In: Ricœur, Paul: $D u$ texte à l'action. Paris: Ed. Du Seuil, 1998, p. 113-132.

RICEUR, Paul. Qu'est-ce qu'un texte? In : RICEEUR, Paul, Du texte à l'action. Paris: Ed. Seuil, 1998, p. 153-178.

RICEUR, Paul. Teoria da intepretação: o discurso e o excesso de significação. Trad. Artur Morão. Lisboa: Edi. 70, 2009.

RICCEUR, Paul. Tempo e narrativa I. Trad. Constança Marcondes Cesar. Campinas: Papirus, 1994.

RICEEUR, Paul. Tempo e narrativa II. Trad. Marina Apenzeller. Campinas: Papirus, 1995.

VANHOOZER, Kevin, Philosophical antecedents to Ricœur's Time and narrative. Org. WOOD, David. On Paul Ricœur: narrative and interpretation. Londres, Routledge, 1991 (arquivo kindle).

\section{Notas}

1 Cf. o capítulo "Não contar mais?", de História e narração em Walter Benjamin, de Jeanne Marie Gagnebin, p. 66. Aproveitamos a oportunidade aqui da referência para assinalar a importância da referida obra para nosso percurso na obra de Walter Benjamin.

${ }^{2}$ Cf. BENJAMIN, O narrador, p. 200.

${ }^{3}$ BENJAMIN, O narrador, p. 201.

${ }^{4}$ BENJAMIN, O narrador, p. 203-204.

${ }^{5} \mathrm{O}$ caso deste último é particularmente desconcertante, uma vez que em ensaio posterior, "Sobre alguns temas em Baudelaire", Poe será apresentado como inventor de uma forma literária totalmente ligada à nova situação do habitante

Cadernos Benjaminianos, Número especial, Belo Horizonte, 2013, página 41-54 
da cidade grande, a narrativa policial, através da analise que Benjamin faz aí do conto "O homem da multidão".

${ }^{6}$ BENJAMIN, Sobre alguns temas em Baudelaire, p. 106.

${ }^{7}$ BENJAMIN, O narrador, p. 213.

${ }^{8}$ Ibidem.

${ }^{9}$ BENJAMIN, O narrador, p. 212.

${ }^{10}$ BENJAMIN, O narrador, p. 214.

11 BENJAMIN, O narrador, p. 213. Cf. a parábola que abre o ensaio "Experiência e pobreza", na qual um moribundo transmite a seus filhos uma parábola, que a princípio entendida ao pé da letra pelos filhos, só iria ser compreendida propriamente pelos jovens herdeiros depois de alguns equívocos, revelando, só então, a riqueza de ensinamento das palavras do pai. BENJAMIN, Experiência e pobreza, p. 114.

${ }^{12}$ BENJAMIN, O narrador, p. 213.

${ }^{13}$ BENJAMIN, O narrador, p. 214.

${ }^{14}$ BENJAMIN, O narrador, p. 213.

${ }^{15}$ Cf. nosso artigo "A construção do crítico: Benjamin e os românticos".

${ }^{16}$ BENJAMIN, O conceito de crítica de arte no romantismo alemão, p. 76.

${ }^{17}$ BENJAMIN, O conceito de crítica de arte no romantismo alemão, p. 77.

18 " [...] a obra de arte singular deve ser dissolvida no medium da arte, mas esse processo só pode ser representado de maneira coerente através de uma pluralidade de críticos que se substituem, se esses forem não intelectos empíricos, mas graus de reflexão personificados". BENAJMIN, O conceito de crítica da arte no romantismo alemão, p. 76.

${ }^{19}$ BENJAMIM, Imagens do pensamento, p. 220.

${ }^{20}$ Resumimos aqui a "dialética do evento e da significação" (cf. RICCEUR, "La fonction herméneutique de la distanciation”. In: Du texte à l'action, p. 117). Essa dialética é descrita com mais detalhes em Teoria da interpretação: $o$ discurso e o excesso de significação.

${ }^{21}$ RICEEUR, Teoria da interpretação, p. 55.

${ }^{22}$ A respeito da relação da hermenêutica da narratividade de Ricœur e a noção heideggeriana de ser-no-mundo como possibilidade, ver o ensaio de Kevin Vanhoozer, "Philosophical antecedents to Ricœur's Time and Narrative". (WOOD, On Paul Ricour: narrative and intepretation).

${ }^{23}$ RICEUR, "La fonction hermeneutique de la distanciation", p. 127; trad. nossa.

24 "O que importa compreender não é a situação inicial do discurso, mas o que aponta para um mundo possível, graças à referência não ostensiva do texto. A compreensão tem menos do que nunca a ver com o autor e a sua situação. Procura apreender as posições de mundo descortinadas pela referência do texto". RICEEUR, Teoria da interpretação, p. 122.

${ }^{25}$ RICEEUR, Tempo e narrativa, v. I, p. 120.

26 "Intepréter, c'est prendre le chemin de pensée ouvert par le texte, se mettre en route vers l'orient du texte. Nous sommes invités par cette remarque à corriger notre concept initial d'inteprétation et à chercher, en deçà de l'opération subjective de l'intérprétation comme acte sur le texte, une opération objective de l'interprétaion qui serai l'acte $d u$ texte. [...] Ce qui est intéressant ici, c'est

Cadernos Benjaminianos, Número especial, Belo Horizonte, 2013, página 41-54 
que l'interprétation, avant d'être l'acte de l'exégète, est l'acte du texte: la relation entre tradition et interprétation est une relation interne au texte; interpréter, pour l'exégète, c'est se mettre dans le sens indiqué par cette relation d'interprétation portée par le texte lui-même." RICEUR, Qu'est-ce qu'un texte?, p. 175.

${ }^{27}$ Como diz Umberto Eco, um praticante deste tipo de leitura da leitura, a "experiência de reler um texto ao longo de quarenta anos me mostrou como são bobas as pessoas que dizem que dissecar um texto e dedicar-se a uma leitura meticulosa equivale a matar sua magia. Toda vez que releio Sylvie, embora conheça o livro de modo tão anatômico - talvez porque o conheça tão bem -, apaixono-me por ele novamente, como se o estivesse lendo pela primeira vez". ECO, Seis passeios pelos bosques da ficção, p. 18.

${ }^{28}$ RICEEUR, Tempo e narrativa, v. II, p. 15-54.

${ }^{29}$ RICEUR, Tempo e narrativa, v. I, p. 101-109. 